\title{
Nitrogen Rate and Planting Density Effects on Yield and Nitrogen Utilization Efficiency of Direct Seeded Rape (Brassica napus)
}

\author{
Qian Zhao ${ }^{1,2}$, Xiaoqin Tian ${ }^{1,3}$, Zhuo $\mathrm{Li}^{1{ }^{13 *}}$ and Yonghong $\mathrm{Liu}^{1,3}$ \\ ${ }^{1}$ Crop Research Institute, Sichuan Academy of Agriculture Sciences, Chengdu 610066, P.R. China \\ ${ }^{2}$ College of Landscape Architecture and Art, Northwest A\&F University, Xianyang 712000, P R. China \\ ${ }^{3}$ Key Laboratory of Water-Saving Agriculture for Hilly Areas of Southern China in Sichuan Province, Chengdu 610066, P.R. \\ China
}

*For correspondence: lizhuo_2000@sina.com

Received 26 August 2020; Accepted 29 November 2021; Published 30 January 2022

\begin{abstract}
The high yield of crops mainly depends on the interaction between nitrogen $(\mathrm{N})$ fertilization and planting density. The present study evaluated the influence of different $\mathrm{N}$ application rates and planting density on the yield and $\mathrm{N}$ utilization efficiency of direct seeded rape during the 2016-2017 and 2017-2018 growing seasons. The three $\mathrm{N}$ application rates including $108 \mathrm{~kg} \mathrm{~N}$ $\mathrm{ha}^{-1}, 144 \mathrm{~kg} \mathrm{~N} \mathrm{ha}^{-1}$ and $180 \mathrm{~kg} \mathrm{~N} \mathrm{ha}^{-1}$ were laid out into main plots while planting density including $15.0 \times 10^{4}, 22.5 \times 10^{4}$, $30.0 \times 10^{4}$ and $37.5 \times 10^{4}$ plants ha $^{-1}$ respectively into sub-plots. The results showed that suitable planting density was the premise to gain high rapeseed yield and the contribution of planting density to rapeseed yield was small when it surpassed a certain value. The highest yield in the two growing seasons was achieved at $144 \mathrm{~kg} \mathrm{~N} \mathrm{ha}^{-1}$ with planting density of $30.0 \times 10^{4}$ plants $\mathrm{ha}^{-1}$. The rapeseed yield increased linearly as $\mathrm{N}$ uptake of the seed part increased, but at high planting density, there was no increase in yield with the increase $\mathrm{N}$ uptake of non-seed parts (stem + husk) when rapeseed yield exceeded a certain value. High planting densities raised shoot $\mathrm{N}$ uptake and $\mathrm{N}$ transfer to rapeseed seeds with the increase of density and $\mathrm{N}$ utilization efficiency was also improved. The too much $\mathrm{N}$ application resulted in more $\mathrm{N}$ accumulation in non-seed parts without increasing production. Under the same target yield, the increased planting density can save 32.4-65.7\% of $\mathrm{N}$ fertilization compared with the conventional planting density. The combination of different $\mathrm{N}$ fertilization rates and planting densities is helpful to increase rapeseed yield. The best $\mathrm{N}$ management strategy is to achieve high yield and reduce the environmental risk to reduce the $\mathrm{N}$ fertilization at suitable high density. (C) 2022 Friends Science Publishers
\end{abstract}

Keywords: Directed sowing rape; Nitrogen fertilization; Planting density; Yield; Nitrogen utilization efficiency

\section{Introduction}

Nitrogen (N) fertilizer has been widely used to improve the yield of crops, but inadequate $\mathrm{N}$ inputs resulted in low yields and food shortages (Sims et al. 2013). In the modern intensive agricultural production system, up to $50 \%$ of the $\mathrm{N}$ fertilizer applied into farmlands is lost to the environment (Cameron et al. 2013). Managing agricultural nutrients to provide secure and reliable food supply while protecting the ecological environment remains one of the major challenges today (Zhang et al. 2007; Cui et al. 2014).

Optimization of the $\mathrm{N}$ application rate is an important direction to achieve food and environmental safety (Helmers et al. 2012). The agronomic indicators are necessary to consider in determining the optimal $\mathrm{N}$ application rate (Jin et al. 2012). For instance, plant density management has a crucial impact on the $\mathrm{N}$ application rate (Gao et al. 2009), while higher plant densities can significantly improve the $\mathrm{N}$ uptake and utilization efficiency in crops (Cong et al. 2020). Studies have reported that for achieving the target yield, high-density planting can reduce the $\mathrm{N}$ application rate by $22.8-25.4 \%$ compared with lowdensity planting (Li et al. 2014).

With urbanization, the rural labor engaged in agriculture is seriously insufficient and the labor cost is rising (Hui 2013). In order to coordinate the relationship among crop production, labor cost and target yield, increased $\mathrm{N}$ fertilizer application under low-density planting to improve the growth of individual plant or decreased $\mathrm{N}$ fertilizer application to reduce the competition among plants under high-density planting was advocated (Ren et al. 2017). Previous studies have shown that the change of $\mathrm{N}$ fertilizer rates and planting densities would affect $\mathrm{N}$ loss and $\mathrm{N}$ cycling between plants and soil, resulting in environmental costs (Gao et al. 2009). Consequently, further understanding of the interaction between the $\mathrm{N}$ fertilizer rate and the planting density on crop yield and $\mathrm{N}$ utilization is of great significance to optimize $\mathrm{N}$ application

To cite this paper: Zhao Q, X Tian, Z Li, Y Liu (2022). Nitrogen rate and planting density effects on yield and nitrogen utilization efficiency of direct seeded rape (Brassica napus). Intl J Agric Biol 27:43-52 
and achieve high levels of output with low environmental costs (Abdul et al. 2018; Fang et al. 2018).

As one of the major oil crops in China, rape is widely planted in most regions because of its high oil content and economic value. Rapeseed oil accounts for $55 \%$ of the total output of oil crops in China, which shows that rape plays an important role in oil crops (Scarisbrick et al. 1982). However, with the increase of labor cost and the low mechanization of rape production compared with other crop productions, farmers grow less rape, resulting in strong demand for oil products. At present, the self-sufficiency rate of oil is only about $40 \%$ and the safety of edible vegetable oil is still under serious threat (Özcan et al. 2014). Since the short growth period and large population of direct seeding rape, the increase of population number makes the branch site move up which is more conducive to mechanized harvesting. The individual development of direct seeding rape is relatively poor, and the formation of yield needs to give full play to the group advantage. Therefore, the establishment of appropriate group structure is an effective way to ensure the high yield of direct seeding rape.

With the purpose of save labor, low-density planting is always adopting in practice, which produces more branches and a great number of pods per plant (Scarisbrick et al. 1977). Whereas, with the planting density increasing, the number of branches and pods per plant decreased, which led to the decrease of yield per plant (Scarisbrick et al. 1977; Velázquez et al. 2018). As one of major factors contributing to rapeseed yield, $\mathrm{N}$ fertilizer could efficiently control the number of pods per plant. The optimized management of $\mathrm{N}$ fertilizer can promote the growth of plants and increase the number of pods per plant, and partly balance the number of pods reduced due to the increase of planting density (Ahmadi and Bahrani 2009; Ren et al. 2017; Zheng et al. 2020).

The change on planting density could affect the crop morphology, alter the utilization of resources and induce different yields react to different $\mathrm{N}$ application rates (Zheng et al. 2020). At low density, increasing $\mathrm{N}$ fertilizer rates will increase the number of pods per plant and improve the yield, but the potential $\mathrm{N}$ losses will also increase at the same time. By contrast, under high density, the relationship between plant population and yield per plant would be better coordinated by reducing the application rates of $\mathrm{N}$ fertilizer without affecting the seed yield and increasing the environmental cost (Zhang et al. 2014).

Therefore, this study mainly analyzed the influences of the $\mathrm{N}$ fertilizer rate and the planting density on yield and $\mathrm{N}$ utilization of direct seeding rape while providing the basis for the reasonable $\mathrm{N}$ application under the condition of increasing density.

\section{Materials and Methods}

\section{Site characteristics}

The experiment was carried out from September 2016 to
May 2017 and September 2017 to May 2018 in Jianyang city $\left(30^{\circ} 16^{\prime} 26.32^{\prime \prime} \mathrm{N}, 104^{\circ} 26^{\prime} 30.38^{\prime \prime} \mathrm{E}\right)$, the west of Sichuan Basin, Sichuan province, southwest China with subtropical monsoon climate and annual precipitation of 600-1200 $\mathrm{mm}$. The annual average temperature ranges between -5 to $37.5^{\circ} \mathrm{C}$ with about 300 days of frost-free period. The soils of the experimental site are purple. The chemical properties of the soil were shown in table (Table $1)$.

\section{Experimental design and management}

A two-factor split plot experiment was designed using a random arrangement with three replicates. The individual plot area was $20 \mathrm{~m}^{2}(4.0 \mathrm{~m} \times 5.0 \mathrm{~m})$. There were three fertilization treatments in main plots, including 108, 144 and $180 \mathrm{~kg} \mathrm{~N} \mathrm{ha}^{-1}$. The sub-plot planting densities treatments included were four $15.0 \times 10^{4}$ plants $\mathrm{ha}^{-1}$ (plant and row spacing: $20 \mathrm{~cm} \times 33.3 \mathrm{~cm}$ ), $22.5 \times 10^{4}$ plants ha $^{-1}$ (plant and row spacing: $13.3 \mathrm{~cm} \times 33.3 \mathrm{~cm}), 30.0 \times 10^{4}$ plants $^{-1}$ (plant and row spacing: $10 \mathrm{~cm} \times 33.3 \mathrm{~cm}$ ), $37.5 \times 10^{4}$ plants ha ${ }^{-1}$ (plant and row spacing: $8 \mathrm{~cm} \times 33.3 \mathrm{~cm}$ ).

Except for the different dosage of $\mathrm{N}$ fertilizer, $\mathrm{K}, \mathrm{P}$ and $\mathrm{B}$ fertilizer was the same under each treatment at $90 \mathrm{~kg}$ $\mathrm{K}_{2} \mathrm{O}$ ha $^{-1}$ and $90 \mathrm{~kg} \mathrm{P}_{2} \mathrm{O}_{5} \mathrm{ha}^{-1}$ using urea $(46 \% \mathrm{~N})$, potassium chloride $\left(60 \% \mathrm{~K}_{2} \mathrm{O}\right)$ and calcium superphosphate $\left(\begin{array}{ll}12 \% & \mathrm{P}_{2} \mathrm{O}_{5}\end{array}\right)$ as fertilizer sources. The basal fertilizers, including $70 \%$ of the $\mathrm{N}$ fertilizer and whole $\mathrm{K}, \mathrm{P}$ fertilizers were incorporated one day before transplanting. The remaining $30 \% \mathrm{~N}$ fertilizer was top dressed at the stem elongation period.

Chuanyou 36, a leading rape variety in Sichuan province, was used as the material in this experiment. In late September, the seedlings were raised and thinned at first leaf stage. Final singling was carried out in the three-leaf stage. During the experiment, plant protection measures such as pest and disease control and herbicide application were followed as local practice. Nonetheless, no obvious problems of weeds and pests in these two growing seasons was observed.

\section{Soil sample collection}

The soil-sampling scheme was the same during two seasons. Soil samples were taken from the $0-20 \mathrm{~cm}$ and $20-40 \mathrm{~cm}$ depth per plot by five points sampling method before transplanting. The content of total $\mathrm{N}$ and $\mathrm{N}$, including available $\mathrm{P}$ and $\mathrm{K}$, organic matter and $\mathrm{pH}$ were measured.

\section{Plant sample collection}

During both growing seasons, plants were harvested separately and all the plants per plot were gleaned to evaluate rapeseed yield; 10 samples per plot were randomly selected to count the number of pods per plant, the number of seeds per pod and 1000-seed weight at maturity. 


\section{Dry matter determination}

The mature plant samples were classified and put into the sample bag according to the organs; the enzymes were deactivated at $105^{\circ} \mathrm{C}$ in the oven for $30 \mathrm{~min}$, then dried the plant organs at $80^{\circ} \mathrm{C}$ and measured for dry weight (Zhang et al. 2019).

\section{$\mathbf{N}$ content determination and nitrogen use efficiency}

The dried plant samples were ground and the $\mathrm{N}$ content was determined by elemental analyzer. Dry weight and $\mathrm{N}$ content of different plant parts were used to calculate the amount of $\mathrm{N}$ shoot uptake of each plot (Zhang et al. 2019).

The $\mathrm{N}$ harvest index was calculated as follows:

$\mathrm{N}$ harvest index $(\mathrm{NHI})=$ Rapeseed $\mathrm{N}$ accumulation/Total plant $\mathrm{N}$ accumulation (Tirol-Padre et al. 1996; Dong et al. 2007).

$\mathrm{N}$ internal utilization efficiency $(\mathrm{NUE} \mathrm{kg} \mathrm{kg}-1)=$ Yield $(\mathrm{kg}$ $\mathrm{ha}^{-1}$ ) / Total plant $\mathrm{N}$ accumulation $\left(\mathrm{kg} \mathrm{N} \mathrm{ha}^{-1}\right)$ (Tollenaar et al. 2006; Dong et al. 2007; Caviglia et al. 2014).

$\mathrm{N}$ partial factor productivity $\left(\mathrm{PFP} \mathrm{kg} \mathrm{kg}{ }^{-1}\right)=$ Yield $\left(\mathrm{kg} \mathrm{ha}^{-1}\right) /$ $\mathrm{N}$ fertilizer rates $\left(\mathrm{kg} \mathrm{N} \mathrm{ha}^{-1}\right)$ (Shapiro and Wortmann 2006; Zheng et al. 2020).

\section{Statistical analysis}

The data of both seasons were analyzed using the Microsoft Excel 2007 and SPSS 17.0 (SPSS Inc. Chicago, IL, USA) software. The means were compared using Duncan's test at a 0.05 probability level.

\section{Results}

\section{Rapeseed yield and its components}

The contribution of $\mathrm{N}$ application to rapeseed yield was higher than planting density (Table 2). With $\mathrm{N}$ fertilization increased, rapeseed yield improved under low-density planting treatments. Under low planting density $\left(15.0 \times 10^{4}\right.$ plants $\mathrm{ha}^{-1}, 22.5 \times 10^{4}$ plants $\mathrm{ha}^{-1}$ ) and $180 \mathrm{~kg} \mathrm{~N} \mathrm{ha}^{-1}$ rapeseed yields was highest; and at high planting density $\left(30.0 \times 10^{4}\right.$ plants ha ${ }^{-1}, 37.5 \times 10^{4}$ plants ha $\left.{ }^{-1}\right)$ with $144 \mathrm{~kg}$ $\mathrm{N}$ ha $^{-1}$, rapeseed yields were highest.

Between years, rapeseed yield were higher during 2016-2017 growing season than 2017-2018, similar response of rapeseed yield to $\mathrm{N}$ application and planting density were observed (Table 2 ). The high-density planting greatly increased the rapeseed yield. Compared to $108 \mathrm{~kg} \mathrm{~N}$ $\mathrm{ha}^{-1}$ and $15.0 \times 10^{4}$ plants $\mathrm{ha}^{-1}$, the rapeseed yield increased by 51.3 and $45.9 \%$ for $108 \mathrm{~kg} \mathrm{~N} \mathrm{ha}^{-1}$ and $37.5 \times 10^{4}$ plants $\mathrm{ha}^{-1}$ in 2016-2017 and 2017-2018 growing seasons, respectively.

The alterations of pods per plant with $\mathrm{N}$ application and planting density were similar during these two growing seasons (Fig. 1). High-density planting suppressed the number of pods per plant. The number of pods per plant under $15.0 \times 10^{4}$ plants ha $^{-1}$ was higher than other planting density treatments. The $\mathrm{N}$ fertilization remarkably increased the number of pods per plant, and the number of pods per plant at the treatment of $180 \mathrm{~kg} \mathrm{~N}^{-1}$ was always the largest no matter what density treatment was.

There was no significant difference in seeds per pod and 1000-seed weight under different treatments (Fig. 1). As the number of pods per plant was significantly higher in 2016-2017, the number of seeds per pod in 2016-2017 was significantly greater than 2017-2018 (Fig. 1). The average number of seeds per pod was 21.2 and 15.3 in the 20162017 and 2017-2018 seasons, respectively.

The relationship between rapeseed yield and yield components showed a significant positive correlation between $\mathrm{N}$ fertilization rate, planting density and rapeseed yield, the correlation coefficient between $\mathrm{N}$ fertilizer rates and rapeseed yields was higher than of densities and rapeseed yields (Fig. 2). The number of pods per plant and seeds per pod were positively correlated with rapeseed yield, while the 1000-seed weight negatively correlated with rapeseed yield. Compared with the correlation between rapeseed yield and group yield components, the correlation between rapeseed yield and individual yield components was relatively weak.

\section{Shoot N Uptake}

Similar to rapeseed yield, the $\mathrm{N}$ application and density had a significant impact on shoot $\mathrm{N}$ uptake of rapeseed at maturity (Table 3 ).

Under the same $\mathrm{N}$ treatment, high-density planting obviously increased the shoot $\mathrm{N}$ uptake of rapes. Compared with $15.0 \times 10^{4}$ plants ha $^{-1}$ density, shoot $\mathrm{N}$ uptake increased by an average of $12.5,32.6,33.0 \%$ and $13.5,36.9$, $37.6 \%$ at $22.5 \times 10^{4}$ plants ha ${ }^{-1}, 30.0 \times 10^{4}$ plants $^{-1}$ and $37.5 \times 10^{4}$ plants $\mathrm{ha}^{-1}$ in 2016-2017 and 2017-2018, respectively.

Compared with planting density, $\mathrm{N}$ fertilizer application has more effect on shoot $\mathrm{N}$ uptake and it was generally the highest under $180 \mathrm{~kg} \mathrm{~N} \mathrm{ha}{ }^{-1}$. Nevertheless, there was no obvious difference of shoot $\mathrm{N}$ uptake at $180 \mathrm{~kg}$ $\mathrm{N} \mathrm{ha}^{-1}$ under high-density planting.

The relationships between shoot $\mathrm{N}$ uptake and rapeseed yield at different planting densities was improved linearly as seed $\mathrm{N}$ uptake, and slope at different densities was similar, which indicated that the yield value of $\mathrm{N}$ uptake per seed under different densities was approximately equal (Fig. 3).

At the two growing seasons, $\mathrm{N}$ uptake of non-seed parts (stem + husk) was changed at different densities. Under low planting densities, rapeseed yield improved linearly as the $\mathrm{N}$ uptake of non-seed parts increased. However, rapeseed yield no longer improved with the $\mathrm{N}$ uptake of non-seed parts increasing when the rapeseed yield reached a certain value under the high-density treatment. These indicate that the non-seed part of rape could not form higher rapeseed yield when it absorbed more $\mathrm{N}$ under high density treatment. 


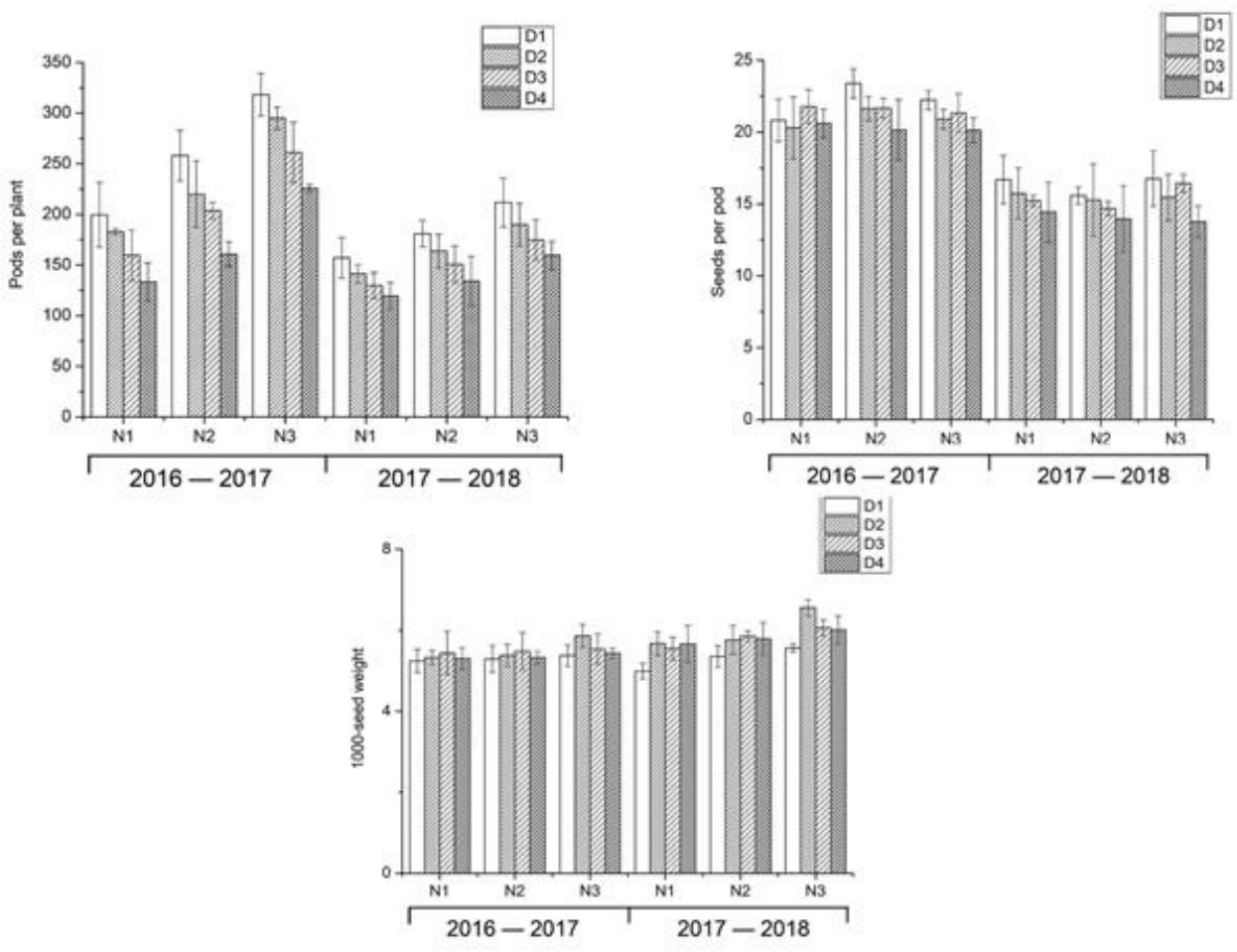

Fig. 1: Yield components under different N fertilizer rates and planting densities during 2016-2017 and 2017-2018 growing seasons in Jianyang city, southwest China

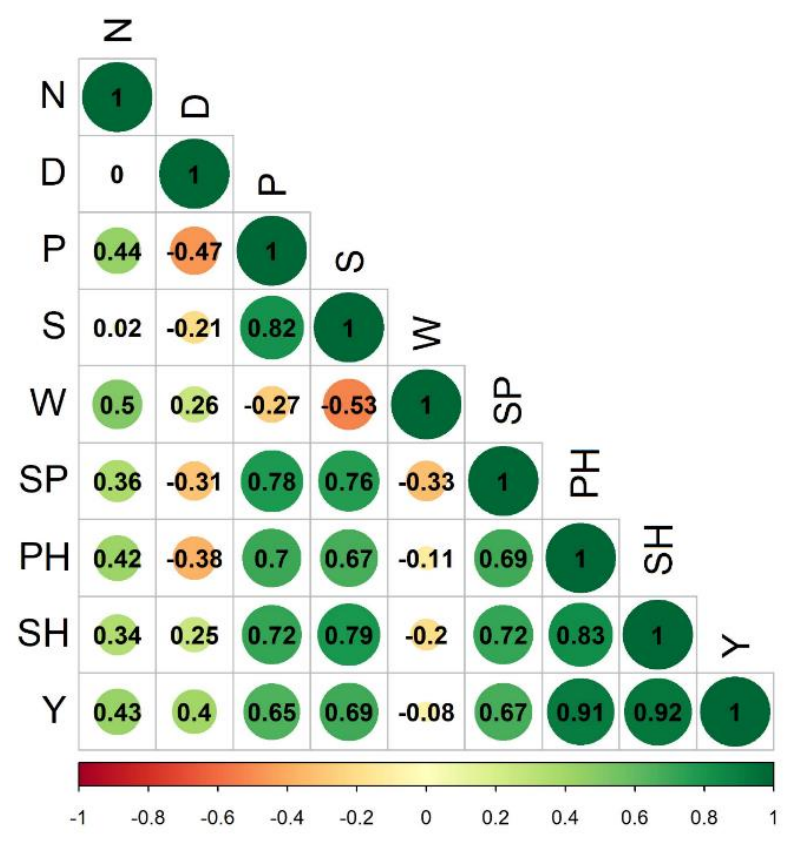

Fig. 2: Correlation matrix between different parameters of rapeseed yield. $\mathrm{N}$ represents $\mathrm{N}$ fertilizer rate, D represents planting density, $\mathrm{P}$ represents pods per plant, $\mathrm{S}$ represents seeds per pod, W represent 1000-seed weight, SP represents seeds per plant, PH represent pods per ha, SH represents seeds per ha, Y represents rapeseed yield. The number in the circle represents the determination coefficient

\section{N Utilization Rate}

Reducing the application rates of $\mathrm{N}$ fertilizer significantly improved the $\mathrm{N}$ harvest index (NHI), internal utilization efficiency (NUE) and its partial factor productivity (PFP). All indicators were maximum at $108 \mathrm{~kg} \mathrm{~N} \mathrm{ha}^{-1}$, which were significantly higher than $144 \mathrm{~kg} \mathrm{~N} \mathrm{ha}^{-1}$ and $180 \mathrm{~kg} \mathrm{~N} \mathrm{ha}^{-1}$ in the two growing seasons.

The NHI and the PFP increased with the increasing of planting density, with the highest for $30.0 \times 10^{4}$ plants $^{-1} a^{-1}$ and $37.5 \times 10^{4}$ plants $\mathrm{ha}^{-1}$, significantly higher than $15.0 \times$ $10^{4}$ plants $\mathrm{ha}^{-1}$. However, the NUE decreased with the increase of density.

During both growing seasons, the NHI at the level of $108 \mathrm{~kg} \mathrm{~N} \mathrm{ha}^{-1}$ was 18.7 and $14.9 \%$ higher on average than $180 \mathrm{~kg} \mathrm{~N} \mathrm{ha}{ }^{-1}$. NUE was 34.4 and $39.0 \%$ higher, respectively While PFP was 21.3 and $39.5 \%$ higher, respectively (Table 4-6).

In the 2016-2017 growing season, the NHI, NUE and PFP under low $\mathrm{N}$ and high planting density $\left(108 \mathrm{~kg} \mathrm{~N} \mathrm{ha}^{-1}\right.$ and $37.5 \times 10^{4}$ plants $\mathrm{ha}^{-1}$ ) were $43.9,16.2$ and $79.0 \%$ higher than under high $\mathrm{N}$ and conventional planting density $\left(180 \mathrm{~kg} \mathrm{~N} \mathrm{ha}^{-1}\right.$ and $15.0 \times 10^{4}$ plants ha $\left.{ }^{-1}\right)$ and 37.5, 4.0 and 74.8\% higher than 2017-2018 growing season, respectively. In the 2016-2017 growing season, the NHI, NUE and PFP under medium $\mathrm{N}$ and high planting density $\left(144 \mathrm{~kg} \mathrm{~N} \mathrm{ha}^{-1}\right.$ and $37.5 \times 10^{4}$ plants $^{-1}$ ) were 29.3, 6.9 and $50.0 \%$ higher than under high $\mathrm{N}$ and conventional 
Effects of N and Density on Rape / Intl J Agric Biol, Vol 27, No 1, 2022

Table 1: Soil chemical properties at the experimental sites during both growing seasons

\begin{tabular}{|c|c|c|c|c|c|c|}
\hline Year & Organic matter $\left(\mathrm{g} \mathrm{kg}^{-1}\right)$ & $\mathrm{pH}$ & Total N $\left(\mathrm{g} \mathrm{kg}^{-1}\right)$ & available $\mathrm{N}\left(\mathrm{mg} \mathrm{kg}^{-1}\right)$ & available $\mathrm{P}\left(\mathrm{mg} \mathrm{kg}^{-1}\right)$ & available $\mathrm{K}\left(\mathrm{mg} \mathrm{kg}^{-1}\right)$ \\
\hline $2016-2017(0-20 \mathrm{~cm})$ & 6.65 & 7.22 & 1.14 & 68.45 & 13.48 & 84.75 \\
\hline $2016-2017(20-40 \mathrm{~cm})$ & 6.86 & 7.35 & 1.29 & 55.46 & 14.38 & 85.64 \\
\hline 2017-2018（0-20 cm) & 7.78 & 7.12 & 0.07 & 93.47 & 27.30 & 86.50 \\
\hline $2017-2018(20-40 \mathrm{~cm})$ & 8.82 & 7.23 & 0.07 & 77.08 & 29.27 & 88.50 \\
\hline
\end{tabular}

Table 2: Rapeseed yields $\left(\mathrm{kg} \mathrm{ha}^{-1}\right)$ under different $\mathrm{N}$ fertilizer rates and planting densities during 2016-2017 and $2017-2018$ growing seasons

\begin{tabular}{|c|c|c|c|c|c|c|c|c|}
\hline \multirow[b]{2}{*}{ Treatments } & \multicolumn{4}{|c|}{$2016-2017$} & \multicolumn{4}{|c|}{$2017-2018$} \\
\hline & \multicolumn{4}{|c|}{ Plant density $\left(\times 10^{4}\right.$ plants ha $\left.{ }^{-1}\right)$} & \multicolumn{4}{|c|}{ Plant density $\left(\times 10^{4}\right.$ plants ha $\left.{ }^{-1}\right)$} \\
\hline $\mathrm{N}$ application $\left(\mathrm{kg} \mathrm{N} \mathrm{ha}^{-1}\right)$ & 15.0 & 22.5 & 30.0 & 37.5 & 15.0 & 22.5 & 30.0 & 37.5 \\
\hline 108 & $1835 f$ & $2339 \mathrm{e}$ & 2499de & $2776 \mathrm{c}$ & $1514 \mathrm{~g}$ & $1826 f$ & $2262 d$ & $2209 d$ \\
\hline 180 & $2585 d$ & $3013 b$ & $3145 \mathrm{ab}$ & $3097 \mathrm{ab}$ & $2107 \mathrm{e}$ & $2401 \mathrm{c}$ & $2453 b c$ & 2371c \\
\hline ANOVA & F value & $P$ value & & & F value & $\mathrm{P}$ value & & \\
\hline $\mathrm{N}$ & 125.52 & $<0.01 * *$ & & & 168.58 & $<0.01 * *$ & & \\
\hline $\mathrm{N} \times \mathrm{D}$ & 4.28 & $<0.01 * *$ & & & 14.58 & $<0.01 * *$ & & \\
\hline
\end{tabular}

Note: Different lowercase letters in each group (2016-2017 and 2017-2018) indicate significant $(P<0.05)$ differences basing on Duncan's multiple range test. ** $P \leq 0.01 ; * P \leq 0.05$.

Table 3: Shoot $\mathrm{N}$ uptake $\left(\mathrm{kg} \mathrm{N}^{-1}\right)$ under different $\mathrm{N}$ fertilizer rates and planting densities during both growing seasons

\begin{tabular}{|c|c|c|c|c|c|c|c|c|}
\hline \multirow[b]{2}{*}{ Treatments } & \multicolumn{4}{|c|}{$2016-2017$} & \multicolumn{4}{|c|}{ 2017-2018 } \\
\hline & \multicolumn{4}{|c|}{ Plant density $\left(\times 10^{4}\right.$ plants ha $\left.^{-1}\right)$} & \multicolumn{4}{|c|}{ Plant density $\left(\times 10^{4}\right.$ plants ha $\left.{ }^{-1}\right)$} \\
\hline $\mathrm{N}$ application $\left(\mathrm{kg} \mathrm{N} \mathrm{ha}^{-1}\right)$ & 15.0 & 22.5 & 30.0 & 37.5 & 15.0 & 22.5 & 30.0 & 37.5 \\
\hline 108 & $87.1 \mathrm{~g}$ & $101.8 \mathrm{fg}$ & $118.2 \mathrm{def}$ & $124.5 \mathrm{~cd}$ & $73.4 \mathrm{f}$ & $81.3 \mathrm{f}$ & $100.8 \mathrm{~d}$ & $106.6 \mathrm{c}$ \\
\hline 180 & $130.7 \mathrm{~cd}$ & $139.2 \mathrm{bc}$ & $158.9 \mathrm{a}$ & $157.6 \mathrm{a}$ & $101.1 \mathrm{~cd}$ & $115.1 \mathrm{bc}$ & $136.1 \mathrm{a}$ & $135.4 \mathrm{a}$ \\
\hline ANOVA & F value & $P$ value & & & F value & $P$ value & & \\
\hline $\mathrm{N}$ & 43.90 & $<0.01 * *$ & & & 42.23 & $<0.01 * *$ & & \\
\hline Density (D) & 26.16 & $<0.01 * *$ & & & 31.32 & $<0.01 * *$ & & \\
\hline $\mathrm{N} \times \mathrm{D}$ & 0.61 & 0.72 & & & 0.25 & 0.95 & & \\
\hline
\end{tabular}

Note: Different lowercase letters in each group (2016-2017 and 2017-2018) indicate significant $(P<0.05)$ differences basing on Duncan's multiple range test. ** $P \leq 0.01$; * $P \leq$ 0.05 .

Table 4: $\mathrm{N}$ harvest index (NHI) under different $\mathrm{N}$ fertilizer rates and planting densities during both growing seasons

\begin{tabular}{|c|c|c|c|c|c|c|c|c|}
\hline \multirow[b]{2}{*}{ Treatments } & \multicolumn{4}{|c|}{$2016-2017$} & \multicolumn{4}{|c|}{$2017-2018$} \\
\hline & \multicolumn{4}{|c|}{ Plant density $\left(\times 10^{4}\right.$ plants ha $\left.{ }^{-1}\right)$} & \multicolumn{4}{|c|}{ Plant density $\left(\times 10^{4}\right.$ plants ha $\left.{ }^{-1}\right)$} \\
\hline $\mathrm{N}$ application $\left(\mathrm{kg} \mathrm{N} \mathrm{ha}^{-1}\right)$ & 15.0 & 22.5 & 30.0 & 37.5 & 15.0 & 22.5 & 30.0 & 37.5 \\
\hline 108 & $0.50 \mathrm{c}$ & $0.53 b c$ & $0.54 \mathrm{~b}$ & $0.59 \mathrm{a}$ & $0.46 \mathrm{~d}$ & $0.50 \mathrm{bc}$ & $0.51 b$ & $0.55 \mathrm{a}$ \\
\hline 180 & $0.41 \mathrm{e}$ & $0.44 \mathrm{de}$ & $0.49 \mathrm{~cd}$ & $0.48 \mathrm{~cd}$ & $0.40 \mathrm{f}$ & $0.44 \mathrm{de}$ & $0.46 \mathrm{~d}$ & $0.46 \mathrm{~d}$ \\
\hline ANOVA & F value & $\mathrm{P}$ value & & & F value & $P$ value & & \\
\hline $\mathrm{N}$ & 32.15 & $<0.01 * *$ & & & 27.52 & $<0.01 * *$ & & \\
\hline Density (D) & 16.89 & $<0.01 * *$ & & & 19.38 & $<0.01 * *$ & & \\
\hline $\mathrm{N} \times \mathrm{D}$ & 0.74 & 0.62 & & & 0.55 & 0.76 & & \\
\hline
\end{tabular}

Note: Different lowercase letters in each group (2016-2017 and 2017-2018) indicate significant $(P<0.05)$ differences basing on Duncan's multiple range test. ** $P \leq 0.01 ; * P \leq$ 0.05

Table 5: $\mathrm{N}$ internal utilization efficiency (NUE kg kg-1) under different $\mathrm{N}$ fertilizer rates and planting densities during both growing seasons

\begin{tabular}{|c|c|c|c|c|c|c|c|c|}
\hline \multirow[b]{2}{*}{ Treatments } & \multicolumn{4}{|c|}{$2016-2017$} & \multicolumn{4}{|c|}{ 2017-2018 } \\
\hline & \multicolumn{4}{|c|}{ Plant density $\left(\times 10^{4}\right.$ plants $\left.\mathrm{ha}^{-1}\right)$} & \multicolumn{4}{|c|}{ Plant density $\left(\times 10^{4}\right.$ plants ha $\left.^{-1}\right)$} \\
\hline $\mathrm{N}$ application $\left(\mathrm{kg} \mathrm{N} \mathrm{ha}^{-1}\right)$ & 15.0 & 22.5 & 30.0 & 37.5 & 15.0 & 22.5 & 30.0 & 37.5 \\
\hline 108 & $23.67 \mathrm{a}$ & $24.47 \mathrm{a}$ & $21.68 b$ & $20.90 b$ & $21.29 \mathrm{a}$ & $15.23 b$ & $14.30 \mathrm{c}$ & $15.20 \mathrm{~b}$ \\
\hline 144 & $20.82 b$ & $20.17 \mathrm{c}$ & $20.62 b c$ & $19.24 \mathrm{~cd}$ & $17.32 \mathrm{ab}$ & $14.32 \mathrm{c}$ & $14.50 \mathrm{bc}$ & $15.11 \mathrm{~b}$ \\
\hline 180 & $17.99 \mathrm{~d}$ & $17.82 \mathrm{de}$ & 16.01de & $15.69 \mathrm{e}$ & $14.62 b c$ & $10.38 \mathrm{~d}$ & $11.42 \mathrm{~d}$ & $11.07 \mathrm{~d}$ \\
\hline ANOVA & F value & $P$ value & & & F value & $P$ value & & \\
\hline $\mathrm{N}$ & 41.25 & $<0.01 * *$ & & & 39.97 & $<0.01 * *$ & & \\
\hline Density (D) & 4.36 & $<0.05 *$ & & & 21.84 & $<0.01 * *$ & & \\
\hline $\mathrm{N} \times \mathrm{D}$ & 0.69 & 0.66 & & & 0.67 & 0.68 & & \\
\hline
\end{tabular}


Zhao et al. / Intl J Agric Biol, Vol 27, No 1, 2022

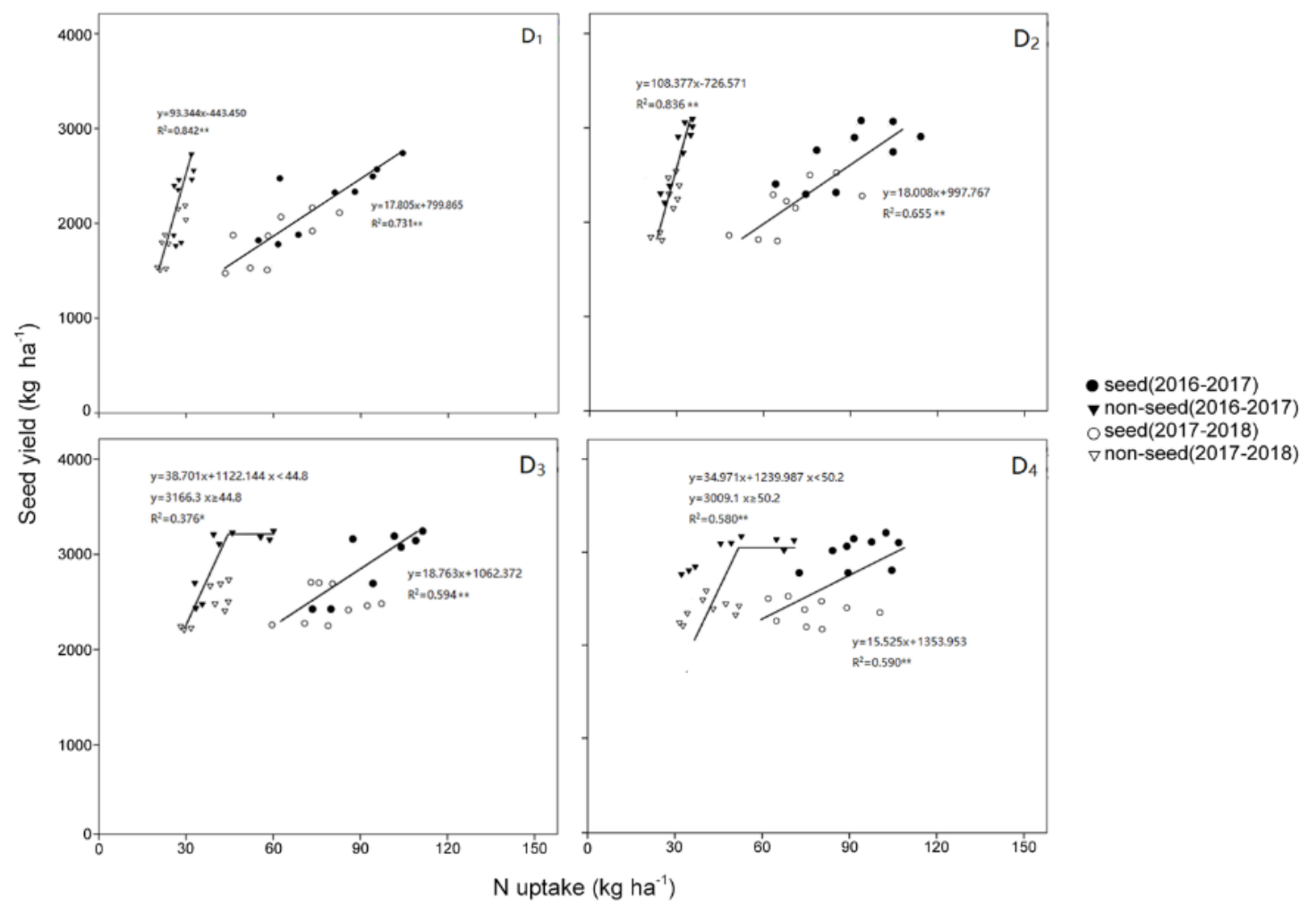

Fig. 3: The relationship between rapeseed yield and $\mathrm{N}$ uptake of seed and non-seed parts under different planting density treatments during growing seasons

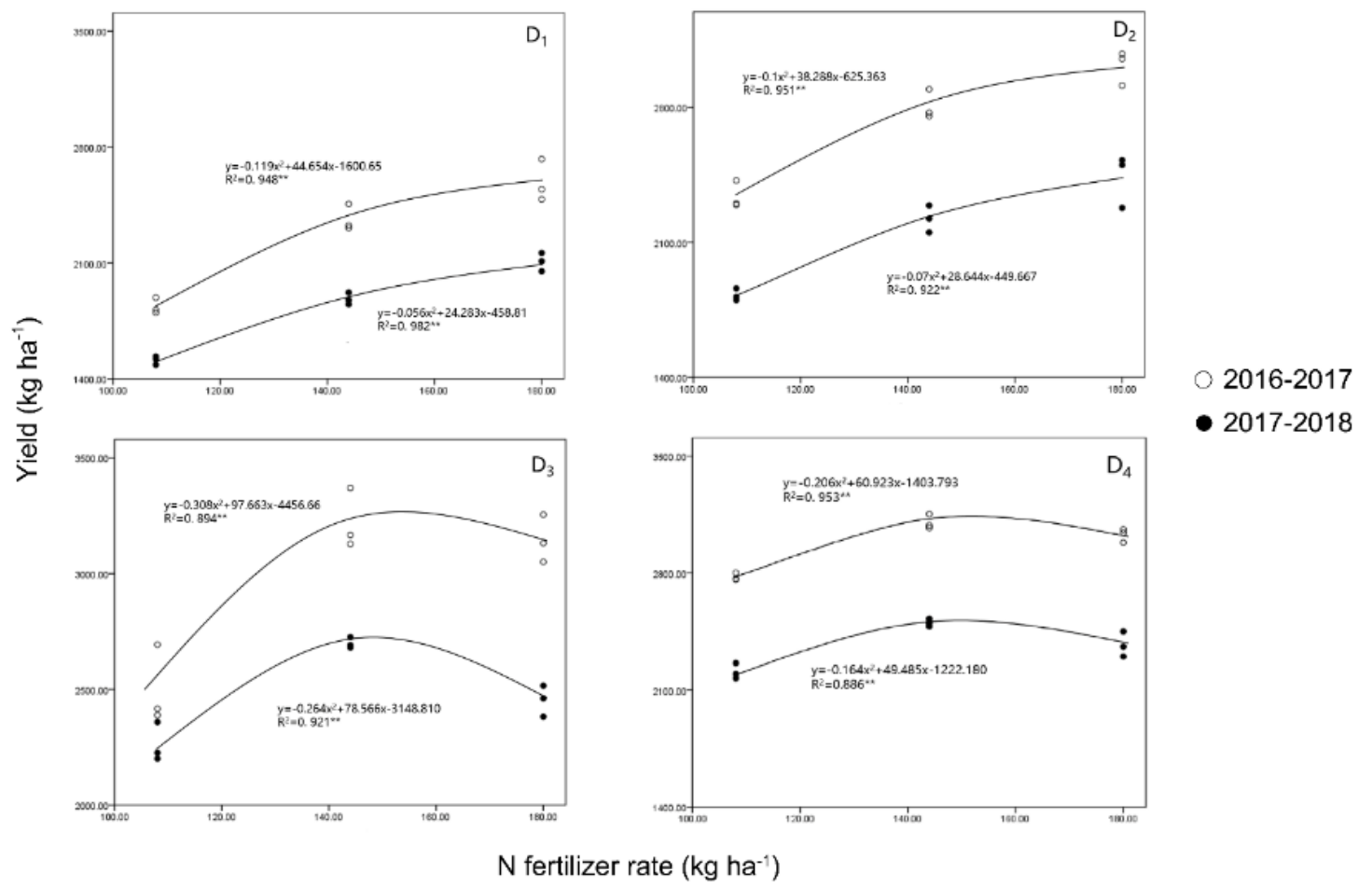

Fig. 4: Effect of $\mathrm{N}$ fertilizer rate and planting density on direct seeding rape yield per unit. 
Effects of N and Density on Rape / Intl J Agric Biol, Vol 27, No 1, 2022

Table 6: Partial factor productivity (PFP kg kg-1) under different $\mathrm{N}$ fertilizer rates and planting densities during both growing seasons

\begin{tabular}{|c|c|c|c|c|c|c|c|c|}
\hline \multirow[b]{2}{*}{ Treatments } & \multicolumn{4}{|c|}{$2016-2017$} & \multicolumn{4}{|c|}{ 2017-2018 } \\
\hline & \multicolumn{4}{|c|}{ Plant density $\left(\times 10^{4}\right.$ plants ha $\left.^{-1}\right)$} & \multicolumn{4}{|c|}{ Plant density $\left(\times 10^{4}\right.$ plants ha $\left.{ }^{-1}\right)$} \\
\hline $\mathrm{N}$ application $\left(\mathrm{kg} \mathrm{N} \mathrm{ha}^{-1}\right)$ & 15.0 & 22.5 & 30.0 & 37.5 & 15.0 & 22.5 & 30.0 & 37.5 \\
\hline 108 & $16.99 \mathrm{e}$ & $21.65 \mathrm{c}$ & $23.14 b$ & $25.71 \mathrm{a}$ & $14.02 \mathrm{e}$ & $16.91 \mathrm{c}$ & $20.94 \mathrm{a}$ & $20.46 a$ \\
\hline 144 & $16.42 \mathrm{e}$ & $19.49 d$ & $22.37 b c$ & $21.55 \mathrm{c}$ & $13.07 \mathrm{f}$ & $15.43 \mathrm{~d}$ & $18.75 b$ & $17.38 \mathrm{c}$ \\
\hline 180 & $14.36 f$ & $16.74 \mathrm{e}$ & $17.47 \mathrm{e}$ & $17.21 \mathrm{e}$ & $11.71 \mathrm{~g}$ & $13.34 \mathrm{f}$ & $13.63 \mathrm{ef}$ & $13.17 f$ \\
\hline ANOVA & F value & $P$ value & & & F value & $P$ value & & \\
\hline $\mathrm{N}$ & 175.33 & $<0.01^{* *} *$ & & & 159.54 & $<0.01^{* * *}$ & & \\
\hline Density (D) & 109.80 & $<0.01^{* *}$ & & & 90.12 & $<0.01 * *$ & & \\
\hline $\mathrm{N} \times \mathrm{D}$ & 9.99 & $<0.01^{* * *}$ & & & 6.75 & $<0.01^{* * *}$ & & \\
\hline
\end{tabular}
0.05

Table 7: $\mathrm{N}$ fertilizer rates of rapeseed based on regression equations under different planting densities

\begin{tabular}{|c|c|c|c|c|c|c|c|c|}
\hline \multirow{3}{*}{ Target yield $\left(\mathrm{kg} \mathrm{ha}^{-1}\right)$} & \multicolumn{4}{|c|}{$\mathrm{N}$ fertilizer rates in $2016-2017$} & \multicolumn{4}{|c|}{$\mathrm{N}$ fertilizer rates in 2017-2018 } \\
\hline & \multicolumn{4}{|c|}{ Plant density $\left(\times 10^{4}\right.$ plants ha $\left.^{-1}\right)$} & \multicolumn{4}{|c|}{ Plant density $\left(\times 10^{4}\right.$ plants ha $\left.{ }^{-1}\right)$} \\
\hline & 15.0 & 22.5 & 30.0 & 37.5 & 15.0 & 22.5 & 30.0 & 37.5 \\
\hline Average yield of Sichuan Province (2389) & 146.69 & 110.78 & 88.52 & 89.47 & - & 168.42 & 115.18 & 123.63 \\
\hline Decrement & - & 35.91 & 58.17 & 57.22 & - & - & 53.24 & 44.79 \\
\hline Decrease & - & $32.4 \%$ & $65.7 \%$ & $64.0 \%$ & & & $46.2 \%$ & $36.2 \%$ \\
\hline
\end{tabular}

planting density $\left(180 \mathrm{~kg} \mathrm{~N} \mathrm{ha}^{-1}\right.$ and $15.0 \times 10^{4}$ plants ha $\left.{ }^{-1}\right)$, respectively. And the NHI, NUE and PFP were 25, 3.4 and $48.5 \%$ higher in the 2017-2018 growing season.

Nonetheless, the NHI and NUE decreased when the application of $\mathrm{N}$ fertilizer was high, which was very easy for plants to absorb a large amount of $\mathrm{N}$, and most of $\mathrm{N}$ absorbed was mostly accumulated in non-economic parts, thus reducing the $\mathrm{N}$ application and increasing planting density can not only realize rapeseed yield and promote $\mathrm{N}$ to rapeseed distribution, but also effectively improve the utilization efficiency of $\mathrm{N}$ fertilizer at the same time.

\section{Comparison of N Fertilizer Dosage under Four Densities}

Regression analysis was carried out between the yield of rapeseed under four densities and the corresponding $\mathrm{N}$ fertilizer dosage (Fig. 4). The fitting degree of the four models has reached an extremely significant level.

According to the model and regression equation, the rates of $\mathrm{N}$ fertilizer were calculated when the rapeseed yield reaches $2389 \mathrm{~kg} \mathrm{ha}^{-1}$ (Table 7). During 2016-2017 growing season, four kinds of density of rapeseed $\mathrm{N}$ fertilizer were $146.69 \mathrm{~kg} \mathrm{ha}^{-1}, 110.78 \mathrm{~kg} \mathrm{ha}^{-1}, 88.52 \mathrm{~kg} \mathrm{ha}^{-}$ ${ }^{1}$ and $89.47 \mathrm{~kg} \mathrm{ha}^{-1}$. During 2017-2018 growing season, $15.0 \times 10^{4}$ plants ha $^{-1}$ level of rapeseed yield has yet to reach an average yield of Sichuan province, so it was unable to calculate the $\mathrm{N}$ fertilizer usage, the $\mathrm{N}$ fertilizer dosage of the other three-density rapeseed was $168.42 \mathrm{~kg}$ $\mathrm{ha}^{-1}, 115.18 \mathrm{~kg} \mathrm{ha} \mathrm{ha}^{-1}, 123.63 \mathrm{~kg} \mathrm{ha}{ }^{-1}$, respectively. Compared with the conventional density $\left(15.0 \times 10^{4}\right.$ plants $\mathrm{ha}^{-1}$ ), increasing the planting density could save $32.4-65.7 \% \mathrm{~N}$ fertilizer. Under the same target yield condition, the rape of high density requires less exogenous $\mathrm{N}$ and the increase of planting density could effectively reduce the rates of $\mathrm{N}$ fertilizer.

\section{Discussion}

The $\mathrm{N}$ fertilization and planting density had crucial impacts on crop yield (Liang et al. 2013; Fang et al. 2018). Previous studies have shown that crop yield frequently exhibited a curve response to $\mathrm{N}$ fertilizer rates or planting densities, and reaches the maximum level under the optimum $\mathrm{N}$ application or planting density (Roques and Berry 2016). The present study showed that rapeseed yield improved linearly with the increase of planting density at low $\mathrm{N}$ levels. However, planting density had a quadratic response at high $\mathrm{N}$ treatments. In this study, the yield of rapeseed at high-density treatments increased by $20.2-32.3 \%$ and $17.2-$ $28.1 \%$ under the condition of constant $\mathrm{N}$ application compared with low-density treatment $\left(15.0 \times 10^{4}\right.$ plants $\mathrm{ha}^{-1}$ ) in two growing seasons, respectively. The rapeseed yield at $180 \mathrm{~kg} \mathrm{~N} \mathrm{ha}^{-1}$ were the highest under low density treatments, but rapeseed yield no longer improve while $\mathrm{N}$ application exceed $144 \mathrm{~kg} \mathrm{~N} \mathrm{ha}^{-1}$ at high density treatments.

$\mathrm{N}$ application could promote crop growth, improve dry matter accumulation and leaf area per plant and reduce variation among plants at the same time (Rossini et al. 2011). The crop growth was poor with a relative low $\mathrm{N}$ supply, and the dry matter of individual plant at the stem elongation period was significantly higher at high $\mathrm{N}$ input treatments (Dong et al. 2012). The competition among plants was healthy even under high-density treatments, and individual plants could still give full play to its yield potential (Tollenaar et al. 2006; Ren et al. 2017). By contrast, high $\mathrm{N}$ supply increased the dry matter accumulation of individual plants (Jiang et al. 2002). The crowding stress among crops under suitable conditions often associated with high $\mathrm{N}$ application and high-density planting, which accelerated the senescence of low canopy leaves, enhancing plant competition, increasing the 
incidence rate of crops and resulting in low yield eventually (Tollenaar et al. 2006; Dong et al. 2012; Antonietta et al. 2014). Therefore, the key to high yield and high efficiency was to pay attention to the coordination of $\mathrm{N}$ application and planting density.

It has been pointed out in previous studies that rapeseed yield in each unit area depends on the planting density, the number of pods per plant, the seeds per pod and the individual seed weight (Diepenbrock 2000). In present study, the impacts of planting density and $\mathrm{N}$ application rate on the number of seeds per pod and the 1000-seed weight were not significant, which might be related to the characteristics of varieties. Consequently, the relationships between rapeseed yield and individual yield components was not very obvious.

The number of pods per plant was remarkably affected by $\mathrm{N}$ fertilizer rate and planting density. The planting density was negatively correlated with the number of pods per plant. The number of pods per plant decreased greatly under high-density treatments. Improving the $\mathrm{N}$ fertilizer rate could promote the growth of individual plants and increase the number of pods per plant (Riffkin et al. 2012; Ren et al. 2017). Studies have shown that the optimal $\mathrm{N}$ fertilization is closely related to the improvement of rapeseed yield components while the number of pods per plant is the most sensitive to $\mathrm{N}$ fertilization. The positive effect of $\mathrm{N}$ application on pods per plant could partially balance the decrease of pod numbers per plant at high density (Ma et al. 2014).

The purpose of rational close planting of rape is to cultivate a population structure with high light efficiency to improve the yield per unit area to obtain high yield (Wholey and Booth 1979; Ren et al. 2017). Although to some extent, the increase of planting density of rape inhibited some characters (such as pods per plant) of rape, however, with the increase of density, the leaf area index and light energy utilization rate of the population were greatly improved, which gave full play to the group effect and finally reflected in the increase of rape groups' yield (Ozer 2003). This study showed that there was a strong correlation between rapeseed yield and yield components, and the number of pods per ha was significant positively correlated with rapeseed yield and the correlation coefficient is relatively high, which was consistent with previous study results (Ozer 2003; Ren et al. 2017; Zheng et al. 2020).

The application of $\mathrm{N}$ fertilizer and planting density significantly affected rapeseed yield and yield components. High-density planting improved rapeseed yield. The number of pods per plant decreased obviously as the planting density increased. The $\mathrm{N}$ fertilizer rate greatly increased the number of pods per plant and the yield of rapeseed, and significantly affected the response of planting density to rapeseed yield. At low density, the yield of rapeseed improved with the increase of the $\mathrm{N}$ fertilizer rate. Under high density, excessive $\mathrm{N}$ application reduced rapeseed yield. The income of rapeseed was the best under the treatment of $144 \mathrm{~kg} \mathrm{~N} \mathrm{ha}^{-1}$ and $30.0 \times 10^{4}$ plants ha $^{-1}$.

One of the main measures to reduce the loss of $\mathrm{N}$ is to reduce the $\mathrm{N}$ fertilization and improve the $\mathrm{N}$ utilization rate. The $\mathrm{N}$ uptake reflects the $\mathrm{N}$ utilization rate (Nakamura et al. 2008; Caviglia et al. 2014).

The rapeseed yield improved linearly as $\mathrm{N}$ uptake increased, and the $\mathrm{N}$ uptake of each seed was similar under different densities. Nevertheless, for the non-seed part (stem + husk), the response of $\mathrm{N}$ uptake to rapeseed yield varied with changes of planting densities. The $\mathrm{N}$ uptake of nonseed part increased without obtaining high rapeseed yield at high density treatments, showing the obvious phenomenon of luxury $\mathrm{N}$ uptake. This change was consistent with previous research results, the competition among plants was invariably fierce under high density and high $\mathrm{N}$ supply, so much more $\mathrm{N}$ was distributed to the non-seed part to promote the competitiveness of plants (Bennett et al. 2011; Ren et al. 2017).

Non-leaf organs played an important role in the photosynthesis and yield formation of rape since the pod development period beginning (Beccafichi et al. 2003; Amanullah 2010; Zhang et al. 2014). High density would lead to shading between plants, so more $\mathrm{N}$ was distributed to the non-seed part to compensate for the decrease of light intensity and the maintenance of photosynthesis (Delagrange 2011; Ren et al. 2017). Although crops at high planting densities absorbed much more $\mathrm{N}$, the absorbed $\mathrm{N}$ was used to improve the competition among plants rather than to obtain high yield. Therefore, it was necessary to optimize the population structure and reduce competition among plants by coordinating $\mathrm{N}$ application and planting density.

High density increased the shoot $\mathrm{N}$ uptake of rapeseed. Under high density and high $\mathrm{N}$ application treatment, the non-seed parts (stem + husk) did not make more contribution to rapeseed yield with the condition of absorbing higher $\mathrm{N}$. Increasing the planting density could promote the transfer of $\mathrm{N}$ to rapeseeds and improve the $\mathrm{N}$ utilization rate. However, excessive application of $\mathrm{N}$ fertilizer would lead to more accumulation of $\mathrm{N}$ in noneconomic parts of rapeseed, which could not achieve the purpose of increasing rapeseed yield.

At present, in order to give full play to the potential of increasing yield of rapeseed, the application rates of $\mathrm{N}$ fertilizer are too large, resulting in low $\mathrm{N}$ fertilizer utilization rate and surplus $\mathrm{N}$ fertilizer ( $\mathrm{Du}$ et al. 2019). Studies have shown that crop yield was closely related to $\mathrm{N}$ uptake and the effects of $\mathrm{N}$ application on its uptake and utilization of crops are different. Instead of increasing crop yield, high $\mathrm{N}$ will lead to decreased $\mathrm{N}$ utilization efficiency, resource waste and environmental security (Anbessa and Juskiw 2012). Some studies also showed that by reducing $\mathrm{N}$ fertilizer and increasing planting density, high crop yield and $\mathrm{N}$ utilization rate can be achieved (O'Beirne and Cassidy 1990).

The results showed that dense planting could improve 
the N utilization efficiency, increase the NHI and the NUE of rapeseed. The NHI reflects the $\mathrm{N}$ transfer to the seeds. In this study, the increase of $\mathrm{N}$ application reduced the NHI and the NUE, which indicates that the increase of $\mathrm{N}$ application is not conducive to the $\mathrm{N}$ transfer to the rapeseeds, and more $\mathrm{N}$ will be used for the physiological activities of the plants themselves. The results were consistent with previous research (Tirol-Padre et al. 1996; Dong et al. 2007). Under low $\mathrm{N}$ fertilizer and high density, PFP is higher, it can be seen that reducing $\mathrm{N}$ application and density planting is the key measure to improve the utilization efficiency of $\mathrm{N}$ fertilizer and effectively save the $\mathrm{N}$ fertilizer rates (Shapiro and Wortmann 2006; Zheng et al. 2020).

From the relationship between rapeseed yield and $\mathrm{N}$ fertilizer dosage, in this study, when the same target yield was achieved, the $\mathrm{N}$ fertilizer dosage of high-density rapeseed was $35.9-58.2 \mathrm{~kg}$ per ha less than regular density $\left(15.0 \times 10^{4}\right.$ plants $\left.\mathrm{ha}^{-1}\right)$ rapeseed, which means that increasing the planting density could save $35.1-61.2 \%$ of $\mathrm{N}$ application. The dense planting is a key method to improve the utilization efficiency of $\mathrm{N}$ fertilizer and effectively save the application of $\mathrm{N}$ fertilizer (Zhang et al. 2019). Thus, reducing the application of $\mathrm{N}$ fertilizer and increasing the planting density at the same time can not only achieve the high yield of rape, promote the distribution of $\mathrm{N}$ to seeds and slow down the $\mathrm{N}$ loss, but also effectively improve the efficiency of $\mathrm{N}$ utilization while protecting the ecological environment.

\section{Conclusion}

The application of $\mathrm{N}$ fertilizer and planting density significantly affected rapeseed yield and yield components. High-density planting improved rapeseed yield. At low density, the yield of rapeseed improved with the increase of the $\mathrm{N}$ fertilizer rate. Under high density, excessive $\mathrm{N}$ application reduced rapeseed yield. The income of rapeseed was the best under the treatment of $144 \mathrm{~kg} \mathrm{~N} \mathrm{ha}^{-1}$ and $30.0 \times$ 104 plants ha ${ }^{-1}$. High density increased the shoot $\mathrm{N}$ uptake of rape. However, excessive application of $\mathrm{N}$ fertilizer would lead to more accumulation of $\mathrm{N}$ in non-economic parts of rape, which could not achieve the purpose of increasing rapeseed yield. Reducing the nitrogen rate and increasing the planting density can realize the high yield of rape and effectively improve the nitrogen use efficiency.

\section{Acknowledgments}

This research was supported by the National Key R \& D Program of China (2018YFD0200703), the Sichuan Provincial Financial Innovation Ability Improvement Project (2016GYSH-007), the Study on the Disaster Mechanism and Control Techniques of Rape Autumn Floods and Spring Droughts in Chengdu-Chongqing Economic Zone (2020ZYD029), the Study on Key Technologies and Integrated Models of Green, High- quality, High-yield and High-efficiency of New Double Cropping Production System in Rape-Maize Dryland (2021XKJS007).

\section{Author Contributions}

QZ and ZL conceived and designed the experiments. QZ, ZL and XQT performed the experiments. QZ, ZL, XQT, and YHL analyzed and interpreted the sequence data. QZ wrote the paper. All authors read and approved the manuscript.

\section{Conflicts of Interest}

The authors declare that the research was conducted in the absence of any commercial or financial relationships that could be construed as a potential conflict of interest.

\section{Data Availability}

All data included in this study are available upon request by contact with the corresponding author.

\section{Ethics Approvals}

Not applicable.

\section{References}

Abdul R, A Larbi, A Opoku, F Tetteh, I Hoeschle-Zeledon (2018). Corralling, planting density, and $\mathrm{N}$ fertilizer rate effect on soil properties, weed diversity and maize yield. Agroecol Sustain Food 43:1-18

Ahmadi M, MJ Bahrani (2009). Yield and yield components of rapeseed as influenced by water stress at different growth stages and nitrogen levels. Amer-Euras J Agric Environ Sci 5:755-761

Amanullah S (2010). Timing and rate of nitrogen application influence grain quality and yield in maize planted at high and low densities. $J$ Sci Food Agric 90:21-29

Anbessa Y, P Juskiw (2012). Nitrogen fertilizer rate and cultivar interaction effects on nitrogen recovery, utilization efficiency, and agronomic performance of spring barley. Intl Sch Res Notes Agron 2012:1-8

Antonietta M, D Fanello, H Acciaresi, J Guiamet (2014). Senescence and yield responses to plant density in stay green and earlier-senescing maize hybrids from Argentina. Field Crop Res 155:111-119

Beccafichi C, P Benincasa, M Guiducci, F Tei (2003). Effect of crop density on growth and light interception in greenhouse lettuce. Acta Hortic 614:507-513

Bennett E, J Roberts, C Wagstaff (2011). The role of the pod in seed development: Strategies for manipulating yield. New Phytol 190:838-853

Cameron KC, HJ Di, JL Moir (2013). Nitrogen losses from the soil/plant system: A review. Ann Appl Biol 162:145-173

Caviglia OP, R Melchiori, V Sadras (2014). Nitrogen utilization efficiency in maize as affected by hybrid and $\mathrm{N}$ rate in late-sown crops. Field Crop Res 168:27-37

Cong R, T Liu, P Lu, T Ren, X Li, J Lu (2020). Nitrogen fertilization compensation the weak photosynthesis of Oilseed rape (Brassca napus L.) under haze weather. Sci Rep 10:1-9

Cui Z, Z Dou, X Chen, X Ju, F Zhang (2014). Managing agricultural nutrients for food security in China: Past, present and future. Agron J 106:191-198

Delagrange S (2011). Light- and seasonal-induced plasticity in leaf morphology, $\mathrm{N}$ partitioning and photosynthetic capacity of two temperate deciduous species. Environ Exp Bot 70:1-10 
Diepenbrock W (2000). Yield analysis of winter oilseed rape (Brassica napus L.): A review. Field Crop Res 67:35-49

Dong G, Y Wang, Y Zhang, P Chen, L Yang, J Huang (2007). Main index of source and sink in nitrogen use efficiency for grain output in conventional indica rice cultivars. Acta Agron Sin 33:43-49

Dong H, W Li, E Egrinya, D Zhang (2012). Nitrogen rate and plant density effects on yield and late-season leaf senescence of cotton raised on a saline field. Field Crop Res 126:137-144

Du Q, L Zhou, P Chen, X Liu, C Song, T Yong (2019). Relay-intercropping soybean with maize maintains soil fertility and increases nitrogen recovery efficiency by reducing nitrogen input. Crop J 8:140-152

Fang X, H She, C Wang, X Liu, Y Li, Z Yi (2018). Effects of fertilizer application rate and planting density on photosynthetic characteristics, yield and yield components in waxy wheat. Cer Res Commun 46:169-179

Gao Y, Y Li, J Zhang, W Liu, Z Dang, Q Qiang (2009) Effects of mulch, N fertilizer, and plant density on wheat yield, wheat nitrogen uptake, and residual soil nitrate in a dryland area of China. Nutr Cycl Agroecosyst 85:109-121

Helmers MJ, X Zhou, JL Baker, SW Melvin, DW Lemke (2012). Nitrogen loss on tile-drained Mollisols as affected by nitrogen application rate under continuous corn and corn-soybean rotation systems. Can J Soil Sci 92:493-499

Hui X (2013). Analysis of influencing factors of rural labor engaging in nonagricultural employment: Based on the investigation of 728 households in Henan Province. J South Agric 44:530-534

Jiang L, Y Shao, Y Jin, C Li (2002). Effects of the ratio and stage of nitrogen application on yield and dry matter accumulation of superhigh-yield winter wheat. Acta Trit Crops 22:70-73

Jin L, H Cui, B Li, J Zhang, S Dong, P Liu (2012). Effects of integrated agronomic management practices on yield and nitrogen efficiency of summer maize in North China. Field Crop Res 134:30-35

Li YS, CB Yu, S Zhu, LH Xie, XJ Hu, X Liao, XS Liao, Z Che (2014). High planting density benefits to mechanized harvest and nitrogen application rates of oilseed rape (Brassica napus L.). Soil Sci Plant Nutr 60:384-392

Liang Q, T Li, C Meng, Y Jiang, G Zhao, D Wu (2013). Effects of fertilization and planting density on agronomic traits and yield of maize variety Nanxiao 969. J South Agric 44:1856-1860

Ma N, J Yuan, M Li, J Li, L Zhang, X Liu, MS Naeem, C Zhang (2014). Ideotype population exploration: Growth, photosynthesis, and yield components at different planting densities in winter oilseed rape (Brassica napus L.). PLoS One 9:1-15

Nakamura R, N Kachi, J Suzuki (2008). Effects of nutrient distribution pattern and aboveground competition on size of individuals in ipomoea tricolor populations. Botany 86:1260-1265

O'Beirne D, J Cassidy (1990). Effects of nitrogen fertilizer on yield, dry matter content and flouriness of potatoes. J Sci Food Agric 52:351-363

Özcan M, A Ünver, D Arslan (2014). A research on evaluation of some fruit kernels and/or seeds as a raw material of vegetable oil industry. Qual Assur Saf Crop 1:1-5
Ozer H (2003). Sowing date and nitrogen rate effects on growth, yield and yield components of two summer rapeseed cultivars. Eur J Agron 19:453-463

Ren T, B Liu, J Lu, Z Deng, X Li, R Cong (2017). Optimal plant density and $\mathrm{N}$ fertilization to achieve higher seed yield and lower $\mathrm{N}$ surplus for winter oilseed rape (Brassica napus L.). Field Crop Res 204:199-207

Riffkin P, T Potter, G Kearney (2012). Yield performance of late-maturing winter canola (Brassica napus L.) types in the high rainfall zone of southern Australia. Crop Past Sci 63:17-32

Roques SE, PM Berry (2016). The yield response of oilseed rape to plant population density. J Agric Sci 154:305-320

Rossini MA, GA Maddonni, ME Otegui (2011). Inter-plant competition for resources in maize crops grown under contrasting nitrogen supply and density: Variability in plant and ear growth. Field Crop Res 121:373-380

Scarisbrick DH, R Daniels, R Noor (1982). The effect of varying seed rate on the yield and yield components of oil-seed rape (Brassica napus). J Agric Sci 99:561-568

Scarisbrick DH, JM Wilkes, R Kempson (1977). The effect of varying plant population density on the seed yield of Navy beans (Phaseolus vulgaris) in south-east England. J Agric Sci 88:567-577

Shapiro C, C Wortmann (2006). Corn response to nitrogen rate, row spacing, and plant density in eastern Nebraska. Agron J 98:529-535

Sims JT, L Ma, O Oenema, Z Dou, F Zhang (2013). Advances and challenges for nutrient management in China in the $21^{\text {st }}$ century. $J$ Environ Qual 42:947-950

Tirol-Padre A, J Ladha, U Singh, E Laureles, G Punzalan, S Akita (1996). Grain yield performance of rice genotypes at suboptimal levels of soil $\mathrm{N}$ as affected by $\mathrm{N}$ uptake and utilization efficiency. Field Crop Res 46:127-143

Tollenaar M, W Deen, L Echarte, W Liu (2006). Effect of crowding stress on dry matter accumulation and harvest index in maize. Agron $J$ 98:930-937

Velázquez R, R Casquete, A Hernández, A Martín, M Córdoba, T Bartolomé (2018). Effect of plant density and harvesting type on yield and quality of fresh and dried peppers and paprika. J Sci Food Agric 99:400-408

Wholey D, R Booth (1979). Influence of variety and planting density on starch accumulation in cassava roots. J Sci Food Agric 30:165-170

Zhang D, L Zhang, J Liu, S Han, Q Wang, L Li (2014). Plant density affects light interception and yield in cotton grown as companion crop in young jujube plantations. Field Crop Res 169:132-139

Zhang M, G Pan, Y Huang, J He, X Fang, Z Liu, M Zhan (2019). Effects of increased planting density with reduced nitrogen application on yield formation and nitrogen utilization of autumn maize. Agric Sci Technol 20:1-13

Zhang W, TH Ricketts, C Kremen, K Carney, S Swinton (2007). Ecosystem services and dis-services to agriculture. Ecol Econ 64:253-260

Zheng H, Y Chen, Q Chen, B Li, Y Zhang, Q Tang (2020). High density planting with lower nitrogen application increased early rice production in a double-season rice system. Agron J 112:205-214 